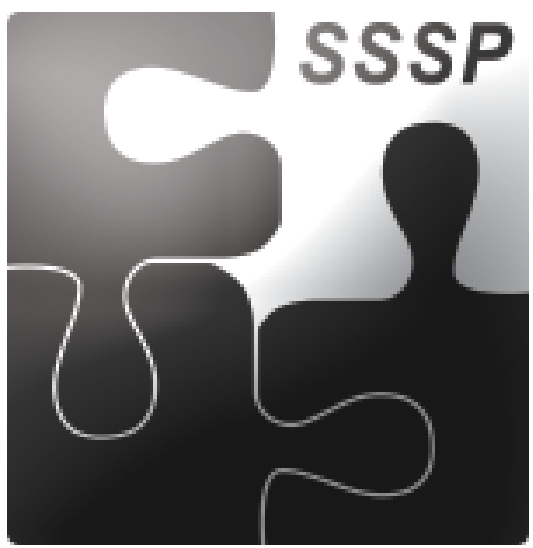

A Neo-Marxian Critique, Formulation and Test of Juvenile Dispositions as a Function of Social Class

Author(s): Timothy J. Carter and Donald Clelland

Source: Social Problems, Vol. 27, No. 1, Policy Processes (Oct., 1979), pp. 96-108

Published by: University of California Press on behalf of the Society for the Study of Social Problems

Stable URL: http://www.jstor.org/stable/800019

Accessed: 19/02/2014 09:21

Your use of the JSTOR archive indicates your acceptance of the Terms \& Conditions of Use, available at http://www.jstor.org/page/info/about/policies/terms.jsp

JSTOR is a not-for-profit service that helps scholars, researchers, and students discover, use, and build upon a wide range of content in a trusted digital archive. We use information technology and tools to increase productivity and facilitate new forms of scholarship. For more information about JSTOR, please contact support@ jstor.org. 
Copyright by the University of California Press. Carter, T.; Clelland, D. (1979). Neo-marxian

critique, formulation and test of juvenile dispositions as a function of social-class. Social Problems, 27(1), 96-108. doi: 10.2307/800019

SOCIAL PROBLEMS, Vol. 27, No. 1, October 1979

\title{
A NEO-MARXIAN CRITIQUE, FORMULATION AND TEST OF JUVENILE DISPOSITIONS AS A FUNCTION OF SOCIAL CLASS*
}

\author{
TIMOTHY CARTER \\ Virginia Polytechnic Institute and State University \\ DONALD CLELLAND \\ University of Tennessee
}

\begin{abstract}
First, this research challenges the methodological adequacy of previous juvenile disposition studies, particularly their conceptualization and measure of social class. Second, a neo-Marxian theory of juvenile court dispositions is presented. This theory distinguishes between two offense patterns (traditional crimes against person and property and crimes against the moral order, status and victimless offenses) in terms of their relative impact on the social relations of production, subsequently revealing distinct disposition trends. Finally, a multivariate test of two propositions derived from this neo-Marxian theory is provided. The findings support the present neo-Marxian theory of juvenile disposition sentencing concerning the strength of greater social class discriminatory tendencies in the disposition of moral as opposed to traditional offenses.
\end{abstract}

Until recently, one of the most widely accepted empirical generalizations in the sociology of crime and juvenile delinquency was the proposition that severity of disposition is negatively related to social class (or socioeconomic status). This proposition appears in a host of criminological texts crossing otherwise competing paradigms. For example, class discrimination in the administration of justice is an essential proposition of the labeling perspective (cf. Wellford, 1975), modern conflict theory (Turk, 1969; Quinney, 1970; Chambliss and Seidman, 1971) and critical criminology (Taylor et al., 1973, 1975; Quinney, 1975, 1977).

Thus, it is with some alarm that advocates of these theories face an accumulated body of evidence which casts doubt on the validity of the claim of class biased dispositions. The narrow empirical base of this proposition has been reexamined by Hagan (1974a) and by Wellford (1975), and neither found a strong relationship between severity of disposition and stratification variables. More recently, Lizotte (1978) found a weak indirect relationship (explaining less than one percent of the variance) between occupational prestige and length of prison sentence. Lizotte's analysis of a subsample of white "proprietors" suggests strongly favorable discrimination in length of sentence. However, most research on socioeconomic bias in the criminal justice system demonstrates no statistically significant relationship whatsoever (cf. Terry, 1967; Hagan, 1974b; Cohen, 1975; Chiricos and Waldo, 1975). It would seem, then, that the labeling theorists, the conflict theorists, and the neo-Marxian critical theorists are faced with a significiant anomaly.

What then is to be done in the face of this challenge? Rather than indulge in dialectical gamesmanship, such as disclaiming the very possibility of testing Marxian hypotheses with bourgeois methodology (cf. Reasons, 1977), we challenge the methodological adequacy of previous studies, present a neo-Marxian theory of juvenile dispositions and provide a multivariate test of two propositions derived from this theory. Among radical criminologists, only Schwendinger and Schwendinger (1976) and Greenberg (1977a) have attempted to provide a Marxist interpretation of juvenile delinquency in capitalist societies; and prior to this study the criminalization processes have been ignored. ${ }^{1}$

* An earlier version of this paper was read at the Annual Meetings of the Southern Sociological Society, Atlanta, April, 1977. We thank Carleton Smith, Stephen Norland, James Michaels and Ellsworth Fuhrman for constructive criticisms.

1. Class discrimination in the administration of justice involves a number of conceptually discrete levels of analysis. This research focuses solely on recommended and judicial disposition. We do not address the im- 


\section{PREVIOUS DISPOSITION RESEARCH: METHODOLOGICAL PROBLEMS}

Rigorous attempts to test for class bias in the juvenile disposition process have been limited to research by Terry (1967) and Cohen (1975), which found no relationship, and Thornberry (1973) and Thomas and Cage (1977), which found low SES to be associated with more severe sentences even with legal variables controlled. But Wellford's (1975) reanalysis of Thornberry's (1973) data disconfirmed his conclusion of class bias; and Thomas and Cage (1977) report only weak associations (.11 to .13 using Cramer's V). Thus, the case for the traditional labeling-conflict proposition is very weak.

However, all of these studies are marred by methodological problems. First, not all studies examine the full range of judicial dispositions. Terry (1967) and Thornberry (1973), for example, simply dichotomize disposition. This would appear to be an inefficient use of data which ignores the substantial variation in disposition.

Second, with the exception of Thomas and Cage (1977), all of these works fail to distinguish between different types of delinquency. Thus, our knowledge of disposition is limited to an array of unspecified juvenile offenses.

Third, all of these studies use questionable measures of class. Previous disposition research fails to provide either theoretical or empirical justification for the choice of class cutting points. It would appear that such research tests for dispositional bias against some vaguely defined working class or against the offspring of blue-collar workers. ${ }^{2}$ The basis for this proposition in terms of class or stratification theory is questionable. Furthermore, Thornberry (1973) and Cohen (1975) measure socioeconomic status by median income or education of census tract of residence. This procedure may introduce measurement error at the individual level (ecological fallacy). Thomas and Cage (1977) divide their sample into four strata based on occupational prestige of the head of household. Despite their treatment of these strata as nominal categories, they do not examine the possibility of specific dispositional bias against the lowest (unskilled) stratum. Thus, they appear to be testing the proposition that the full continuum of occupational prestige is a source of judicial bias. They do not specify a theoretical basis for such a linear model; nor do they indicate any reason why the court might take into account parental prestige. Furthermore, the impact of class on juvenile disposition has rarely been analyzed by means of a complete multivariate design. Only Cohen (1975) has used a multiple regression design.

Finally, previous studies have not specified the theoretical model of society from which the concepts and propositions about the nature of delinquency are drawn. It is ironic, then, that these exercises in abstracted empiricism are used against the labeling-conflict perspective (cf. Wellford, 1975; Chiricos and Waldo, 1975). It would be fitting to first examine what a coherent theory of class-biased sanctioning might be.

It is perhaps no accident that the theoretical base of these studies is so weak, for the labelingconflict tradition from which this research might draw is deficient in several ways. First, selfproclaimed Marxian criminologists (e.g., Quinney, 1975; Platt, 1974; Chambliss, 1973b) rarely make use of orthodox Marxian analytic units, and some (e.g., Taylor et al., 1973) dismiss Marx's own comments on crime as non-Marxian. Second, within the labeling-conflict tradition, there has

portant problems of class bias in the production of law (cf. Platt, 1969, 1974, Hagan and Leon, 1977) or in differential law enforcement (cf. Chambliss, 1973a; Gordon, 1973).

2. Terry obtained parents' occupation from city directories, coded them according to the seven-class Minnesota Scale for Paternal Occupation, which he then trichotomized. Because Terry operationally defined the lower class as the three bottom occupational strata, it appears that he tested a proposition of dispositional bias against blue-collar youth. Because Thornberry and Cohen dichotomize class on the arbitrary basis of median income levels they appear to be testing for the differential treatment of some vaguely defined middle class as compared with some vaguely defined working class. 
been no attempt to present a coherent model of the class structure. Third, only Quinney (1977) recognizes the role of lumpenproletariat in relation to crime. Fourth, all (including Quinney, 1977) fail to delineate the importance of offenses against the moral order as threats to the reproduction of the class system. Therefore, the differential response of the state (through the dispositional practices of the courts) toward distinctive patterns of deviance has been ignored. Even discussions of differential dispositional practices of the juvenile court are rare.

We will attempt to deal with these deficiencies in our theory of juvenile dispositions. ${ }^{3}$ Our analysis of the structure of juvenile dispositions is based on a neo-Marxian model of the class structure of capitalist societies (cf. O'Connor, 1973; Habermas, 1973; Anderson, 1974; Poulantzas, 1975; Wright, 1976; Quinney, 1977).

\section{THEORETICAL FRAMEWORK}

The fundamental class division in all capitalist societies is between those who control the major means of production and those who do not, between those who buy and control the labor power of others and those who must sell their labor power on the market. All in the latter category are members of the working class. But under advanced capitalism this class is increasingly hierarchically fractionated. Upper managerial and professional employees of large corporations and service organizations are increasingly split off from the remainder of the working class by virtue of their secondary command positions and semiautonomous work roles. The other major fractions of the working class are the stable working class (including most white-collar workers, most skilled workers, and many semiskilled workers) and the unstable or marginal working class (all, whatever their skill level or collar color, who hold tenuous occupational positions in low demand in the capitalist marketplace). This latter fraction includes the vast bulk of the unemployed. Below these fractions is the lumpenproletariat, Marx's term for a parasitical class which is occupationally outside of the dominant system of production. ${ }^{4}$

The advanced capitalist system, which has created a stable working class largely in its monopoly sector, has also created a marginal unstable working class in its competitive sector, a sector dependent on a growing body of unemployed and underemployed (Marx's "reserve army") to maintain its low wage structure (cf. O'Connor, 1973). Although the competitive sector is dependent on this surplus labor, the very system which creates this "surplus-population" (Marx, 1967:631) generates massive discontent and a tendency to drop out of the reserve army of the marginal fractions of the working class and into the lumpenproletariat. Because such shifts are a basic threat to the political economy of capitalism, the capitalist state is faced with the problem of the regulation of surplus labor. This problem is accommodated by the increasing intervention of

3. Since the focus of this paper is on juvenile dispositions, we have severely limited our review of the controversies surrounding conflict theories of crime and research on class bias in adult criminal sentencing. The issues, however, are quite similar to those which we address here (cf. Greenberg, 1977b; Hopkins, 1977; Reasons, 1977; Chiricos and Waldo, 1977; Quicker and Schmidt, 1977). As summarized by Chiricos and Waldo (1975), the two basic issues are the poor fit between theory and data and the relevance of conventional methodology for testing conflict propositions. On these broad issues we agree with Chiricos and Waldo that weakly specified conflict theory is at least as problematic as the methodological weakness of previous research and that both theory and praxis can only be damaged by methodological inhibitions.

4. The concept "lumpenproletariat" is apparently a problem to both labeling and neo-Marxian theories of crime and delinquency, which either particularize or deny the category in their haste to express empathy with the plight of the insulated and the injured. In Marx, however, the existence of a lumpenproletariat is a minor but recurring theme. It is "the 'dangerous class,' the social scum, the passively rotting mass thrown off the lowest layers of the old society" (1962:118). It includes "swindlers, pickpockets, tricksters, tinkers, beggars" and the like (Marx and Engels, 1962:442). Contrary to most current usage, the lumpenproletariat is not just another name for the poor. Under advanced capitalism it is a dialectical outgrowth of the competitive sector and the surplus labor force, unintended yet functional in its provision of goods and services and as an alternative channel of mobility. Like the reserve army of the unemployed, it is a necessary component of the political economy of advanced capitalism but its existence poses a continuing threat to that system. 
formal systems of social control, criminal and juvenile courts, into the private sociocultural life of the marginal fractions of the working class. In a large part, juvenile delinquency laws and sentencing practices are a response to the contradictions generated by the existence of the surplus labor population (Platt, 1974).

\section{The Juvenile Court}

The juvenile court act of 1899 was primarily intended to control the normative behavior of youth, that is, "their recreation, leisure, education, outlook on life, attitudes to authority, family relationships and personal morality" (Platt, 1969:99), thereby inventing "new categories of youthful deviance" (Platt, 1969:145) and increasing state participation in capitalist domination. Because the reproduction of the capitalist order demands moral hegemony, state control through the legal order must regulate the obstinate motivational system; that is, it must regulate the people who challenge or refuse loyalty or whose beliefs and activities neutralize the system of domination and moral hegemony of the capitalist ideology (Habermas, 1973). In short, the concept "juvenile delinquent" is a bourgeois invention (cf. Fox, 1970 and Platt, 1969) used to distinguish for treatment those youth whose activities represent threats to capitalist hegemony. The juvenile courts' emphasis on the control of morality functions to secure the social, economic and political order by giving state sanction to the system of class domination. Therefore, the class bias of the juvenile system of justice is revealed in the functions and consequences of the institutions and policies of that system in relation to the material conditions of capitalist society and subsequent system of class domination, rather than in the conscious class control motives of those who support or directly participate in the juvenile system.

\section{Juvenile Dispositions}

Excluding cases of the dependent and neglected, the juvenile court handles two conventional types of crimes: crimes against the moral order (i.e., status and victimless offenses) and "traditional offenses" (i.e., crimes against person and property). ${ }^{5}$ Early delinquent reform efforts reveal an emphasis on the former, especially when the transgressors are members of the lower class (Platt, 1969; Fox, 1970; Bremmer, 1970, 1971; Mennel, 1973). An examination of the impact that these two types of crimes have on the social relations of production reveals distinct sentencing trends.

\section{Crimes Against the Moral Order}

Moral offenses, when patterned, threaten the value system which induces stable participation in the work force and also threaten the general legitimacy of the system which is provided by supporting values. The sanctioning of status offenses (e.g., disorderly conduct, truancy, running away, incorrigibility) and victimless moral offenses (e.g., drugs, alcohol and sex) is essential for the reproduction of the capitalist system. Laws regulating sexual desires and behaviors are intended to foster and protect the established monogamous family pattern, which is the major unit for consumption and for the reproduction and training of the labor force (Zaretsky, 1973).

Youth who withdraw their interests and participation from school and rebel against parental authority endanger the process of socialization into wage-labor production roles which are necessary for the maintenance of the capitalist system. Persons who use alcohol or other drugs for es-

5. The crimes of murder, forcible rape, robbery, assault, burglary, auto-theft, larceny, weapons possession, vandalism, arson, receiving stolen property, and violation of probation represent the "Crimes against persons and property" or "Traditional crimes" category. "Status and/or victimless Crimes" are comprised of the following: minor sex offenses, violation of drug laws, drunkenness, disorderly conduct, running away, truancy, ungovernable-behavior and the possessing or drinking of alcohol. 
cape rather than adjustment disrupt capitalist patterns of distribution and consumption (Spitzer, 1975).

State control is needed most where the system of cultural hegemony is the least effective. Therefore, the state directs the enforcement of morality toward the unstable segments of the working class (lower class): the lumpenproletariat and the reserve army of the unemployed, where the threat of dropping into the permanent unproductive ranks of the lumpenproletariat is greater. The tendency of youth to drop into the ranks of the lumpenproletariat may produce life forms and activities contrary to the values of ambition, responsibility, achievement, deferred gratification and respect for private property, which complement the competitive ideology necessary to induce workers to perform labor under alienating conditions in a society based on substantial inequalities. Thus, the court reaffirms the legitimacy of the system of class domination and moral superiority of the bourgeois value system.

In the case of stable working class moral delinquents, the court can generally trust the normal system of class domination to continue its attempts at socialization, because the system of class domination is most effective among this segment of the population where the realization of rewards from productive participation is more likely. The court, as an agent of the state, cannot trust the unstable working class in the same way. Therefore, the severity of punishment in the sentencing of juveniles for moral transgressions, status and victimless offenses will be more strongly directed against youth from the unstable working class. This hypothesis is consistent with the traditional labeling-conflict proposition.

\section{Crimes Against Persons and Property}

In contrast to crimes against the moral order, we believe the class bias in juvenile sentencing for crimes against persons and property cannot be analytically derived from Marxian premises of class dominance. ${ }^{6}$ On the contrary, within capitalist societies, crimes against property clearly threaten the system of private property; and crimes against persons, even when perpetuated against members of the working class, are threats to the legitimacy of the state as the provider of order.

Crimes against persons and property are direct threats to all classes. They represent behavioral rejections of consensual norms. Continued assaults or thefts are perceived to be serious and in need of official control regardless of the offenders' class position. Repeated offenses indicate the failure of socialization agencies and are met with increasingly severe sanctions, particularly institutionalization. However, these sanctions are unrelated (or weakly related) to class membership or occupational status because such distinctions are unrelated to adherence to the property and personal safety norms which these crimes violate. The alternatives in disposition available to the court depend first on the "risk of danger" (Matza, 1969) evident in the juvenile's present offense and prior record. Therefore, legal variables, such as type of offense, number of petitions filed, number of previous police contacts and number of previous offenses, are the major determinants of severity of sentence for offenses against persons and property.

6. Such a deduction, that the need for controlling the surplus labor force necessarily culminates in more stringent control of the labor force regardless of the offense (property or moral), is the conventional implication of radical and neo-Marxian criminology (cf. Taylor et al., 1973, 1975; Spitzer, 1975; Quinney, 1977). Yet, as we do, one could well infer from a Marxian perspective that juveniles who commit acts against property will be treated alike regardless of class position because acts against property must be uniformly suppressed in a capitalist society since the sine qua non of capitalism is the private ownership of property. However, we do not wish to dispute all previous neo-Marxian propositions concerning the class bias in the application of capitalist justice regarding property crimes. One's class position and subsequent ability to pay for superior legal defense results in class-biased dispositions for adults, especially for those in managerial and professional occupations who have been accused of "white-collar" property crimes. 
The "risk of danger" from crimes against person and property crosses class lines. On the other hand, the "risk of danger" from status and victimless crimes is class specific. Therefore, the research hypotheses are:

(I) For person or property crime offenses, the severity of disposition is no greater for juveniles from the unstable working class than for those from the stable working class.

(II) For status or victimless crime offenses, the severity of disposition is greater for juveniles from the unstable working class than for those from the stable working class.

\section{METHODOLOGY}

The data for this study were obtained from the juvenile court records in a metropolitan area of the southeastern United States. The data for each case were obtained from the "Life History" information sheet filled out by individual case workers.

A random sample of approximately twenty-five percent ( 350 cases) of the available population (1,397 cases) was drawn from a complete list of cases for the last six months of 1974.' Of the cases sampled, 104 were handled "unofficially" (i.e., there was no judicial disposition). The remaining sample of 246 cases was divided according to the type of offense, traditional crimes against person or property (116 cases) and status or victimless offenses (130 cases).

The dependent variable, disposition, is ordinal, allowing for variation in sentencing. Furthermore, sentencing is assessed at two court disposition levels, the disposition recommended by case workers and the final judicial disposition, in order to reduce the impact of potentially idiosyncratic judgments.

Previous research on the relation between "social class" and disposition have relied on socalled objective measures of "socioeconomic status." Such measures are always theoretically weak because of their conceptual ambiguity. They would be particularly weak for testing our hypotheses because of their weak tie to the neo-Marxian conception of class developed in this study. Fortuitously, the measure which was available for this study was the subjective assessment of social class made by the case worker assigned to the particular case. The case worker used "lower," "lower middle," "middle" and "upper middle" class labels. These distinctions were then collapsed into "lower" versus everything else. The cutting point for dichotomization is based on our theory. The combination of lower middle, middle and even upper middle class is justifiable in Marxian terms because nearly all of these people are members of the "stable working class." Discussions with the case workers revealed that the criteria for lower class placement are marginality of occupation, income and values. ${ }^{8}$ This operationalization of social class combines emphasis on membership in the surplus labor force and lumpenproletarian values. Although this is not an ideal measure (because it combines dimensions which may be independent) our contention is that it is better than objective measures for testing the present formulation because it is a pragmatic definition used in the everyday life of the court for the purpose of aiding the judge in making sentencing decisions.

7. A complete list of cases for the entire year and previous years could not be obtained due to the previous method of filing. These data were collected in 1975. Many of the cases for that year were still active and distributed among various case workers, thus unobtainable.

8. The social worker's distinction between "lower middle" and "middle" and "upper middle" approximates traditional occupation, education and income measures of class. However, the distinction between "lower class" and "lower middle class" is not made on the basis of occupation, education or income per se. Instead, work and income stability are emphasized. The chronically unemployed as well as persons dependent upon state or federal aid are classified as "lower class." Also, in several instances where both occupation prestige and income are low, the crucial factor for the social worker's social class judgment is "values." In this situation families expressing traditional middle class values (e.g., hardwork, deferred gratification and achievement motivation) will most likely be evaluated as "lower middle" class. If these values are not apparent the family will most likely be evaluated as lower class. 


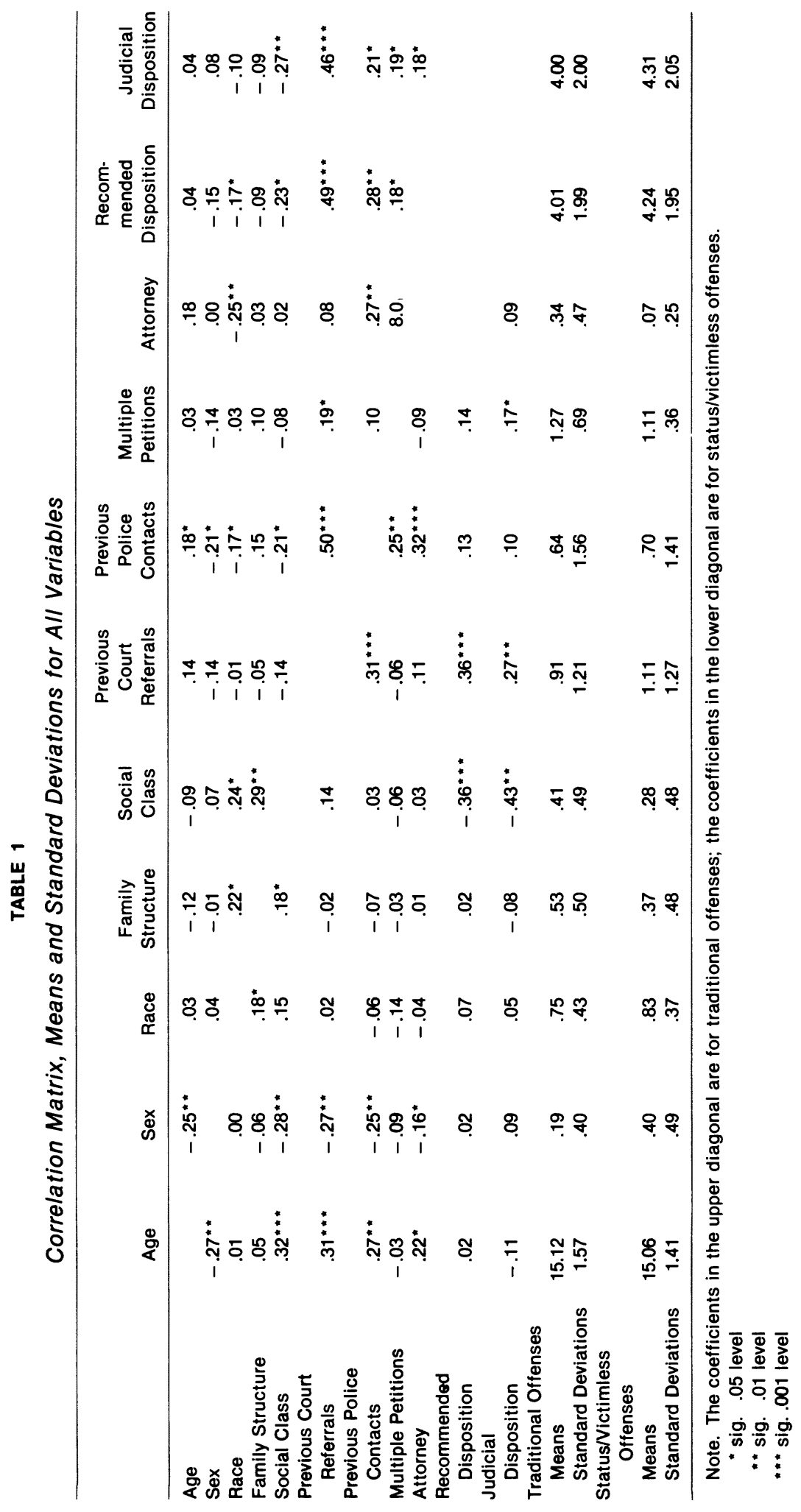


TABLE 2

Regression of Severity of Disposition on Predictor Variables, Standard Regression Coefficients

\begin{tabular}{|c|c|c|c|c|}
\hline & \multicolumn{2}{|c|}{ Traditional Offenses } & \multicolumn{2}{|c|}{ Status/Victimless Offenses } \\
\hline & $\begin{array}{l}\text { Recommended } \\
\text { Disposition }\end{array}$ & $\begin{array}{l}\text { Judicial } \\
\text { Disposition }\end{array}$ & $\begin{array}{l}\text { Recommended } \\
\text { Disposition }\end{array}$ & $\begin{array}{c}\text { Judicial } \\
\text { Disposition }\end{array}$ \\
\hline Age & -.09 & -.06 & .04 & -.08 \\
\hline Sex & -.10 & -.02 & .07 & .08 \\
\hline Race & -.08 & -.02 & .13 & .14 \\
\hline Family Structure & -.06 & .01 & .08 & -.01 \\
\hline Social Class & -.16 & $-.22^{\star}$ & $-.46^{* * *}$ & $-.45^{\star \star \star}$ \\
\hline Previous Court Referrals & $.45^{\star \star \star}$ & $.47^{\star \star \star}$ & $.45^{\star \star *}$ & $.39^{\star \star \star}$ \\
\hline Previous Police Contacts & -.09 & -.13 & -.08 & -.04 \\
\hline Multiple Petitions & .06 & .07 & $.19^{\star}$ & $.21^{*}$ \\
\hline Attorney & & $.18^{\star}$ & & .13 \\
\hline $\mathrm{R}^{2}$, Full Model & .28 & .24 & .32 & .32 \\
\hline
\end{tabular}

$* .05$ level

* * 01 level

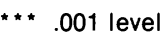

Finally, the present study used standardized multiple regression analysis, thus allowing for the estimation of the relative explanatory power of several independent variables. Several variables that might influence disposition were controlled, variables that might otherwise "distort" or "suppress" the relationship between social class and disposition. The selection of control variables was based upon their availability and use in previous research.

Independent variables entered in the full regression equation included as interval measures: age; previous court referrals; previous police contacts; and number of formal complaints. Other independent variables were: attorney (present or not); sex and race of juvenile; family structure (broken home or two parent home) and social class (unstable or stable working class). Categories of the dependent variable, dispositions, were ranked in the following order from least to most severe: dismissed, fined, suspended commitment, probation, suspended commitment and probation and confinement. ${ }^{9}$

\section{RESULTS}

The Pearson's product-moment (zero-order) correlations between all nine variables and recommended and judicial disposition are presented in Table I. Table I reveals no significant multicollinearity. Since the test of hypotheses is based on the standardized regression coefficients, the zero-order correlations are discussed only in reference to the more conclusive standardized regression coefficients.

Table II presents beta coefficients and significance levels at both disposition levels for both types of offense. Also presented in Table II is the proportion of variance explained for both dependent variables by the full regression model. In the full regression model 28 percent of the vari-

9. Dichotomized measures included in this analysis are treated as "dummy variables." Disposition, an ordinal variable, is treated as interval. This technique has been discussed by Bohrnstedt and Carter (1971), Labowitz (1970), Boyle (1970) and Land (1969). In disposition literature, Hagan (1974b) utilized a similar measurement procedure. 
ance in recommended disposition and 24 percent of the variance in judicial disposition is explained by the inclusion of all predictor variables for the "traditional" offense category. For status and victimless offenses the full regression model explains 32 percent of the variance at both disposition levels.

For traditional offenses there was a striking similarity between the patterns of disposition sentencing for the two disposition levels. The only significant coefficients were for prior court records at both disposition levels and for presence of an attorney and social class at the judicial disposition level. The significant zero-order correlations between number of previous police contacts, number of petitions filed and severity of disposition were also eliminated when other variables were controlled.

Number of prior court referrals had the strongest impact on severity of disposition at both sentencing levels. As the number of prior court referrals increased, the severity of disposition increased. This finding is consistent with previous disposition research (Terry, 1967; Thornberry, 1973; Cohen, 1975; Thomas and Cage, 1977).

Although the association between presence of an attorney and severity of disposition is statistically significant, it is in the opposite direction from what would be expected. Specifically, the presence of an attorney was associated with more severe judicial dispositions. This is contrary to the findings of previous research (Lemert, 1967; Cox, 1967). (This finding is, of course, independent of "severity" as measured by previous police contact, previous court referrals and multiple petitions.) In addition, a breakdown of the data by specific offense revealed no pattern of association between type of offense and presence of attorney nor between type of offense and severity of sentence. Judicial resentment toward attorneys in juvenile court, noted by Cox (1967) and by Dedmon (1975) may be reflected in the disposition sentencing practices of the juvenile judge. While it is reasonable to assume that the disruptive potential of a lawyer in the regular work flow and routine of the juvenile court may create a resentment that may be reflected in dispositions, these data present a research anomaly. Approximately two-thirds of the attorneys representing juveniles in this particular court are practicing law students from a nearby law school. Because they are not licensed attorneys, it is possible that their unsophisticated practices and idealistic beliefs may be viewed as especially disruptive and intolerable by the judge.

Social class bias in the dispositions of traditional of fenders emerges at the final level of sentencing. The judge in this particular court treated lower class offenders more severely than their stable working class counterparts. Therefore, hypothesis (I) is rejected at the judicial disposition level. For recommended disposition hypothesis (I) cannot be rejected. ${ }^{10}$ Although the traditional offense category includes diverse crimes (see footnote 5), judicial class bias cannot be attributed to a relation between social class and offense seriousness. Lower class offenders comprise 54.3 percent of the traditional of fenders and 56.9 percent of the status and/or victimless offenders. The average disposition score for traditional of fenders is 4.02 and 4.20 for status and/or victimless of-

\footnotetext{
10. At a reviewer's suggestion, a regression for judicial disposition including recommended disposition among the independent variables was performed. The association between recommended and judicial dispositions yields a beta coefficient of strong magnitude for both traditional and status and/or victimless offense categories (.64 and .71 respectively). The judicial class bias for traditional offenders reduced below statistical significance $(-.15)$ with recommended disposition in the regression formula. This finding supports our original hypothesis. Unstable working class youth receive a more severe recommended disposition from probation of ficers and these recommendations are strongly related to the final disposition of the case. Similarly, Hagan (1975) found that the probation officers' recommendations strongly affect the final disposition, and that class affects the recommendation. The relationship between the probation officer's recommendation and the judge's disposition poses a research question beyond the scope of our data. Are judges avoiding responsibility by following probation officers' recommendations, or have probation officers' learned to tailor their recommendation by previous judicial disposition patterns?
} 
fenders. Cross tabulary analysis reveals no significant difference between types of offense and social class for either the traditional or status and/or victimless offenses. ${ }^{11}$

The predicted social class bias in the sentencing of status and/or victimless offenders is supported by these data. Youths identified as "lower class" are recommended for a more severe disposition and receive a more severe disposition. Therefore, hypothesis (II) was not rejected. The negative association between social class and court dispositions for status and/or victimless offenders is of such magnitude that, had this sample not been divided, it would appear that lower class offenders receive a more severe disposition. Thus, the importance of specifying type of offense (predicted from our neo-Marxian theory of juvenile dispositions) has been empirically validated.

The analysis of the sentencing of status and/or victimless offenders further demonstrates the importance of a juvenile's past behavior and persistence. Status and/or victimless offenders who have had previous court referrals and multiple petitions (formal complaints) received more severe dispositions. The relative strength of a previous record holds in magnitude regardless of the type of offense. The significance of multiple petitions is a property of status and/or victimless offenses. These objective indicators of patterned moral recalcitrance reflect a threat (conscious or unconscious) to the legitimacy of capitalist ideological domination, necessary for the regulation of a docile labor force.

\section{DISCUSSION}

These data, in part, lend support to conflict theories as well as to our more convoluted, or as we prefer, more "sophisticated" neo-Marxian theory. In terms of the strength of greater discriminatory tendencies in the disposition of moral as opposed to traditional offenses, the findings provide stronger support for the neo-Marxian theory of disposition sentencing than for the traditional conflict hypothesis which predicts class bias regardless of the type of offense. Although alternative explanations may be able to account for these findings (after the fact), the strength of the neo-Marxian perspective lies in its conceptual delineation of crimes against the moral order. The creation of moral crime categories and subsequent handling of transgressors cannot be explained apart from their relation to the capitalist mode of production and subsequent system of class domination. The failure to conceptualize this reference to capitalist society in total is a major limitation of contemporary conflict and labeling traditions (cf. Taylor et al., 1973). From a neo-Marxian perspective, the relative impact of moral offenses on the capitalist social relations of production reveal a distinct, class specific, sanctioning trend not evident for traditional crimes against person and property.

The present neo-Marxian theory of juvenile dispositions is limited to an analysis of what happens to those who have been designated as perpetrators of officially defined delinquent acts, and why. Therefore, we deal with the important problem of class and power in the definition of such acts only in a general manner. Similarly, problems of causation, including class base and motivation, are beyond the scope of our formulation. Furthermore, this theory does not address the

11. In addition to cross tabulary analysis, offenses were ranked in the following order from least to most severe: status offenses, victimless offenses, property offenses and person offenses; they were then entered in a regression as an independent variable. The betas were not significant: .04 for recommended disposition and .08 for judicial disposition. The Pearson's product-moment correlation between "seriousness" and social class was also not significant (.13). The nonsignificant association between seriousness of offense and disposition is evident from previous juvenile court disposition studies (cf. Terry, 1967; Thomas and Sieverdes, 1975; Cohen, 1975). The significant relationship between seriousness and disposition reported by Thomas and Cage (1977) is a zero-order correlation only, and although Thornberry (1973) reports a significant relationship between seriousness and disposition, he does not test for significance and controls only for race and class. 
issue of class biases in the reporting of delinquent activities to social control agencies or the issue of class biases in the apprehension process. The question which has been addressed is a minor component of a developing neo-Marxian theory of crime and the legal order.

Marxian and critical sociologists generally feel no compulsion to conclude with an appeal for future research. Although we do not believe that they should limit themselves to a theory which is fully falsifiable, we believe that neo-Marxian theory must be partially testable. We wish to encourage the critical examination and extension of Marxian theory by whatever means possible. We echo Fendrich's (1977:155) recent judgment that "multivariate analysis can be a means to address politically and socially relevant questions" and extend that judgment to Marxian analysis itself.

\section{REFERENCES}

Anderson, C.

1974 The Political Economy of Social Class. Englewood Cliffs: Prentice-Hall.

Boyle, Richard

1970 "Path analysis and ordinal data." American Journal of Sociology 75:461-80.

Bohrnstedt, George and T. Michael Carter

1971 “Robustness in regression analysis.” In H. L. Costner (ed.), Sociological Methodology. San Francisco:Jossey-Bass.

Bremner, Robert H. (ed.)

1970 Children and Youth in America: A Documentary History, Volume I. Cambridge: Harvard University Press.

1971 Children and Youth in America: A Documentary History, Volume II. Cambridge: Harvard University Press.

Chambliss, William J.

1973a "The saints and the roughnecks." Society (November/December): 24-31.

$1973 \mathrm{~b}$ "Functional and conflict theories of crime." MSS Modular Publications 17:1-23.

Chambliss, William J. and R. B. Seidman.

1971 Law, Order and Power. Reading: Addison-Wesley.

Chiricos, G. and P. Waldo.

1975 "Socioeconomic status and criminal sentencing: An empirical assessment of a conflict proposition." American Sociological Review 40:753-72.

1977 “Reply to Greenberg, Hopkins, and Reasons." American Sociological Review 42:181-85.

Cohen, Lawrence

1975 Delinquency Dispositions: An Empirical Analysis of Processing Decisions in Three Juvenile Courts. Washington, D.C.: U.S. Department of Justice, Law Enforcement Assistance Administration.

Cox, S.

1967 "Lawyers in juvenile court." Crime and Delinquency 13:488-93.

Dedmon, G. M.

1975 "The paradox of juvenile justice: A dramaturgical study." Unpublished master's thesis, Virginia Polytechnic Institute and State University.

Fendrich, James M.

1977 "Keeping the faith or pursuing the good life: A study of the consequences of participation in the civil rights movement." American Sociological Review 42:144-57.

Fox, Sanford, J.

1970 “Juvenile justice reform: A historical perspective." Stanford Law Review 22:1186-1239.

Gordon, David M.

1973 "Capitalism, class and crime in America." Crime and Delinquency 19:163-86.

Greenberg, David F.

$1977 \mathrm{a}$ "Delinquency and the age structure of society." Contemporary Crisis 1:197-215.

$1977 \mathrm{~b}$ "Socioeconomic status and criminal sentences: Is there an association?" American Sociological Review 42:174-5.

Habermas, Jurgen

1973 Legitimation Crisis. Boston: Beacon Press.

Hagan

1974a “Extra-legal attributes and criminal sentencing: An assessment of a sociological viewpoint." Law and Society Review 8:357-83.

1974b "Parameters of criminal prosecution: An application of path analysis to a problem of criminal justice." Journal of Criminal Law and Criminology 65:536-44. 
1975 “The social and legal construction of criminal justice: A study of the pre-sentencing process." Social Problems 22:620-37.

Hagan, J. and J. Leon

1977 "Rediscovering delinquency: Social history, political ideology and the sociology of law." American Sociological Review 42:587-98.

Hopkins, Andrew

1977 “Is there a class bias in criminal sentencing?” American Sociological Review 42:176-77.

Labovitz, Sanford

1970 "The assignment of numbers to rank order categories." American Sociological Review 35:515524.

Land, Kenneth C.

1969 "Principles of path analysis." In Edgar F. Borgatta (ed.), Sociological Methodology. San Francisco: Jossey-Bass.

Lemert, Edwin M.

1967 "The juvenile court-quest and realities." In President's Commission on Law Enforcement and Administration of Justice, Task Force Report: Juvenile Delinquency and Youth Crime: 102-103.

Lizotte, Alan J.

1978 "Extra-legal factors in Chicago's criminal courts: Testing the conflict model of criminal justice." Social Problems: 564-80.

Marx, Karl

1962 The Eighteenth Brumaire of Louis Bonaparte. In Karl Marx, Selected Works, Volume I. New

[1852] York: Lawrence and Wishart.

1967 Capital. Volume I. New York: International Publishers. [1867]

Marx, Karl and Frederick Engels.

1962 Manifesto of the Communist Party. In Karl Marx, Selected Works, Volume I. London: Lawrence [1848] and Wishart.

Matza, David

1969 "Delinquency and drift: The impression of inconsistency and individualized justice." Pp. 965-75 in L. M. Friedman and S. Macaulay (eds.), Law and the Behavioral Sciences. New York: Harcourt Brace Jovanovich.

Mennel, Robert M.

1973 Thorns and Thistles. Hanover: University Press of New England.

O'Connor, James

1973 The Fiscal Crisis of the State. New York: St. Martin's.

Platt, Anthony

1969 The Child Savers. Chicago: The University of Chicago Press.

1974 "The triumph of benevolence: The origins of the juvenile system in the United States." Pp. 35689 in Richard Quinney (ed.), Criminal Justice in America. Boston: Little, Brown.

Poulantzas, $\mathrm{N}$

1975 Classes in Contemporary Capitalism. London: New Left Books.

Quicker, J. C. and J. Schmidt.

1977 "A contribution to the critique of bourgeois criminology: The case of criminal sentencing." The Insurgent Sociologist (summer):62-9.

Quinney, Richard

1970 The Social Reality of Crime. Boston: Little, Brown.

1975 Criminology. Boston: Little, Brown.

1977 Class, State and Crime. New York: McKay.

Reasons, Charles E.

1977 “On methodology, theory and ideology." American Sociological Review 43:177-81.

Schwendinger, Herman and Julia Schwendinger

1976 "Delinquency and the collective varieties of youth." Crime and Social Justice 5:7-12.

Spitzer, Steven

1975 "Toward a Marxian theory of deviance." Social Problems 22:638-51.

Taylor, I., R. Walton and J. Young

1973 The New Criminology. London: Routledge and Kegan Paul.

1975 Criminal Criminology. London. Routledge and Kegan Paul.

$\rightarrow$ Terry, Robert M.

1967 "Discrimination in the handling of juvenile offenders by social control agencies." Journal of Research in Crime and Delinquency 4:218-30.

Thomas, C. and R. J. Cage

1977 "The effect of social characteristics on juvenile court dispositions." Sociological Quarterly 18: 237-52.

$\rightarrow$ Thomas, C. and C. M. Sieverdes

1975 "Juvenile court intake: An analysis of discretionary decision-making." Criminology 12:413-32. 
Thornberry, T. P.

1973 "Race, socioeconomic status and sentencing in the juvenile justice system." The Journal of CrimiTurk, Austin T. nal Law and Criminology 64:90-98.

1969 Criminality and Legal Order. Chicago: Rand McNally.

Wellford, Charles

1975 "Labeling theory and criminology: An assessment." Social Problems 22(February):332-345.

Wright, Erik O.

1976 "Class boundaries in advanced capitalist societies." The New Left Review 98:3-41.

Zaretsky, Eli

1973 "Capitalism, the family and personal life: parts 1 and 2." Socialist Revolution (January-April/ May-June):69-126/19-70. 